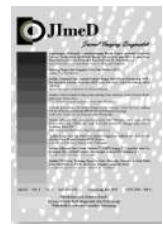

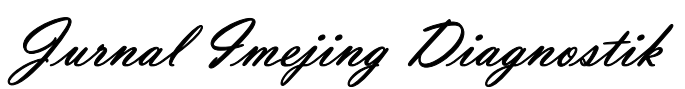

e-ISSN 2621-7457, p-ISSN 2356-301X

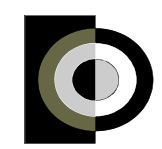

http://ejournal.poltekkessmg.ac.id/ojs/index.php/jimed/index

\title{
Faktor Eksposi terhadap Kualitas Citra Radiografi dan Dosis Pasien Menggunakan Parameter Penilaian Signal to Noise Ratio (SNR) pada Pemeriksaan Thorax Posteroanterior dengan Menggunakan Pesawat Computed Radiografi
}

\author{
Surdiyah Asriningrum ${ }^{1}$, Khaerul Ansory ${ }^{2}$, Putra Tri Hasan ${ }^{3}$ \\ 1,2,3 Politeknik Al Islam Bandung, Indonesia \\ Corresponding Author : Surdiyah Asriningrum \\ e-mail: surdiyahningrum@gmail.com \\ Received: ; Revised: ; Accepted
}

\begin{abstract}
Background: The research was analyzing digital image quality and estimation dose patient by using Signal to Noise Ratio (SNR) on Computed Radiography. SNR can be used for analyzing digital image spatial resolution and estimation dose accurately. The aims of this study to determine the influence of exposure factors on image quality and estimation dose patient.

Methods: This type of research is a quantitative method with an experimental study. Direct experiments in August 2020 assessment with a sample of 9 adults posteroanterior chest photo with the average age of 20-50 years old with an average body weight of 50-69 kilograms.

Results: The measurement results showed that the digital images will be analyzed by SNR, so it can be determined the optimum exposed factor of the highest SNR value and dose radiation. From the analysis, the highest SNR value at $121 \mathrm{kV}$, current $1 \mathrm{mAs}$, the lower dose radiation at $121 \mathrm{kV}$, current $0,9 \mathrm{mAs}$.

Conclusions: There was an influence variation of an exposed factor on the quality of the image and dose to the patient.
\end{abstract}

Keyword: dosage; image quality; signal to noise ratio.

\section{Pendahuluan}

Foto thorax merupakan salah satu penunjang diagnostik yang rutin dilakukan di radiologi dan dilakukan untuk mengevaluasi saluran pernafasan, parenkim dan pembuluh darah paru, mediastinum, jantung, pleura dan dinding thorax. Menurut (Carlton \& Adler, 2001), objek dengan volume yang besar dapat meningkatkan jumlah radiasi hambur yang mengenai film dan mengganggu nilai citra diagnostik, karena pengaruh hamburan radiasi dan rendahnya signal (Bequet et al., 2020).

Penggunan foto thorax pada radiografi digital harus tetap memperhatikan kualitas radiografi meliputi densitas, kontras, serta ketajaman, sehingga perlu dilakukan usaha-usaha untuk menekan faktor-faktor yang dapat menurunkan kualitas, salah satunya adalah faktor eksposi (Bushong, 2013; Uffmann \& Schaefer-Prokop, 2009). Faktor eksposi merupakan faktor yang mempengaruhi dan menentukan kualitas dan kuantitas dari penyinaran radiasi sinar-X yang diperlukan dalam pembuatan gambar radiografi. Faktor eksposi terdiri dari tegangan tabung $(\mathrm{kV})$, arus tabung $(\mathrm{mA})$, dan waktu penyinaran (s) (Ball et al., 1995). Kualitas hasil gambar radiograph dapat dievaluasi dengan dua cara: Objectif dan subjecttif. Penilaian kontras gambar secara subjektif dilakukan melalui pengamatan manusia terhadap hasil radiograph. Penilaian kontras secara objectif menggunakan model matematis untuk menilai kontras secara akurat (Daryati et al., 2019).

Pemberian faktor eksposi yang tepat dapat mengurangi paparan radiasi yang diserap dengan tidak mengurangi hasil visual kualitas citra radiografi (Rasad, 2018). Pemanfaatan radiasi pengion berupa sinar-X pada pemeriksaan radiologi dapat membantu dalam menegakkan diagnosa, akan tetapi selain bermanfaat, apabila terjadi interaksi juga berpotensi menimbulkan efek merugikan bagi pekerja radiasi, pasien, dan masyarakat karena sifat sinar-X dapat mengionisasi bahan sehingga berpotensi merusak jaringan yang dilewatinya dikenal dengan dosis yang dinyatakan sebagai energi yang diserap per unit massa (Utami et al., 2014).

Evaluasi terhadap kualitas gambar dan pengukuran dosis pada Computed Radiography perlu diperhatikan. Perangkat lunak Image $J$ merupakan perangkat yang menilai kualitas 
gambar yang terdapat pada pesawat $C R$ (computed radiography), dengan mengukur nilai piksel kemudian dengan menggunakan SNR (Signal to Noise Ratio) untuk mengukur tingkat noise pada gambar (Ackom et al., 2017; Hastuti et al., 2020).

Tujuan penelitian ini untuk mengetahui pengaruh penggunaan faktor eksposi terhadap kualitas citra dan dosis yang diterima pasien pada pemeriksaan thorax PA Dengan Parameter Penilaian Signal To Noise Ratio (SNR) pada pesawat Computed Radiograph.

\section{Metode}

Penelitian ini merupakan jenis penelitian eksperimen dengan metode kuantitatif, dengan jumlah sampel 9 foto thorax PA dengan rata-rata umur pasien 20-50 tahun dan rata-rata berat badan 50-69 kilogram. Foto dibuat dengan menggunakan grid serta penggunaan faktor eksposi yang bervariasi setelah mendapatkan 9 radiograf thorax PA digital tanpa manipulasi. Untuk menentukan nilai kontras secara objektif tentukan 5 titik Region Of Interst (ROI) yang berbeda pada setiap radiograp dengan menggunakan aplikasi Image $J$ yang outputnya berupa nilai piksel.

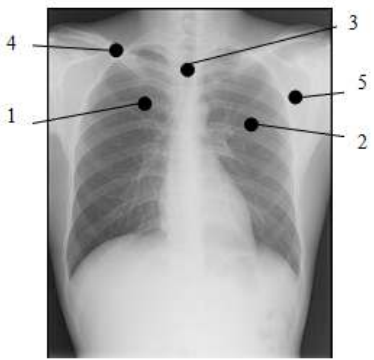

Keterangan :

1. Tulang iga

2. Lapang paru

3. Sternum

4. Klavikula

5. skapula

Gambar 1. Titik ROI

Setelah mendapatkan hasil nilai ROI, kemudian nilai tersebut dimasukan kedalam rumus dibawah ini untuk mendapatkan nilai SNR secara objektif.

$$
S N R=\frac{\text { Mean Signal value within ROI1 }}{\text { Standart deviation of ROI1 }}
$$

Setelah diperoleh nilai SNR dari 5 titik ROI pada 9 radiograf, kemudian menentukan penilaian kontras secara subjektif, penyebaran kuesioner terhadap 10 responden dengan menggunakan skala likert. Parameter penilaian yaitu dengan menilai ketajaman objek yang terdiri dari tulang iga, paruparu dan jantung, kontras dan detail.

\section{Hasil dan Pembahasan}

Pengambilan data dilakukan pada Bulan Agustus 2020, dengan jumlah sampel 9 foto thorax
PA dengan rata-rata umur pasien 20-50 tahun dan rata-rata berat badan 50-69 kilogram dengan faktor eksposi yang sudah ditentukan dengan identitas sebagai berikut.

\begin{tabular}{ccccc}
\multicolumn{5}{c}{ Tabel 1. Identitas Pasien } \\
\hline Sampel & Usia & BB & JK & No RM \\
\hline 1 & 25 th & $60 \mathrm{~kg}$ & Laki-laki & $13622 \times x x$ \\
2 & 41 th & $55 \mathrm{~kg}$ & Laki-laki & $3209 \times x x$ \\
3 & 38 th & $56 \mathrm{~kg}$ & Laki-laki & $3978 \times x x$ \\
4 & 33 th & $69 \mathrm{~kg}$ & Laki-laki & $1402 \times x x$ \\
5 & 39 th & $65 \mathrm{~kg}$ & Laki-laki & $1304 \times x x$ \\
6 & 23 th & $56 \mathrm{~kg}$ & Laki-laki & $4116 \times x x$ \\
7 & 20 th & $56 \mathrm{~kg}$ & Laki-laki & $3918 \times x x$ \\
8 & 35 th & $50 \mathrm{~kg}$ & Laki-laki & $1402 \times x x$ \\
9 & 20 th & $55 \mathrm{~kg}$ & Laki-laki & $2958 \times x x$ \\
\hline
\end{tabular}

\section{Penilaian Kualitas Citra secara Objectif}

Hasil radiograph yang telah didapat, dilakukan 5 titik pengukuran Region Of Interest (ROI) dengan membuat lokasi yang sama untuk semua objek, maka didapatkan hasil SNR sebagai

Tabel 2. Hasil nilai SNR pada radiograf 1 sampai dengan radiograf 9

\begin{tabular}{cccc}
\hline Rad & $\mathrm{kVp}$ & $\mathrm{mAs}$ & $\begin{array}{c}\text { SNR rata- } \\
\text { rata }\end{array}$ \\
\hline 1 & 55 & 8 & 11.254 \\
2 & 58,5 & 8 & 11.717 \\
3 & 60 & 10 & 11.009 \\
4 & 60 & 12,5 & 11.256 \\
5 & 70 & 3,2 & 13.585 \\
6 & 121 & 0,9 & 14.351 \\
7 & 121 & 1 & 18.359 \\
8 & 125 & 1 & 16.065 \\
9 & 125 & 0,9 & 15.338 \\
\hline
\end{tabular}

Dari tabel 2 dapat dilihat bahwa nilai SNR tertinggi adalah 18.359 pada radiograf 7 dan nilai SNR terendah adalah 11.009 pada radiograf 3 . Berdasarkan data pada tabel 2. Apabila faktor eksposi ditingkatkan maka menghasilkan lebih banyak sinyal yang mencapai detektor yang membuat noise berkurang pada citra radiograf. Peningkatan kontras dan noise gambar terlihat ketika mA meningkat

\section{Penilaian Kualitas Citra secara Subjektif}

Penilaian kualitas secara subjektif dilakukan dengan penyebaran kuesioner terhadap 10 responden, maka dihasilkan nilai kuesioner sebagai berikut.

Tabel 3. Hasil penilaian dari 9 radiograf terhadap 10

\begin{tabular}{cc}
\multicolumn{2}{c}{ responden } \\
\hline Rad & Kualitas \\
\hline 1 & 76.5
\end{tabular}




\begin{tabular}{cc}
2 & 76 \\
3 & 80 \\
4 & 71.5 \\
5 & 83 \\
6 & 74 \\
7 & 73.5 \\
8 & 59 \\
9 & 69 \\
\hline
\end{tabular}

Berdasarkan tabel 3, penilian kualitas secara objektif dari hasil 9 radiograf terhadap 10 responden, nilai kualitas tertinggi adalah 83 Sangat Baik terdapat pada radiograf 5 dan nilai kualitas terendah adalah 59 Baik pada radiograf 8. Menurut peneliti penggunaan teknik $\mathrm{kVp}$ yaitu lebih dari $100 \mathrm{kVp}$, menyebabkan perbedaan densitas antar tulang, jaringan dan udara menjadi relatif homogen sehingga detail dan kontras semakin menurun (Bushong, 2008).

\section{Estimasi Dosis Pasien}

Setelah mendapatkan hasil analisa estimasi dosis radiasi yang didapatkan dari hasil audit dosimetri, maka dihasilkan nilai estimasi dosis sebagai berikut.

Tabel 4. Hasil nilai estimasi dosis radiasi terhadap 9

\begin{tabular}{cccc}
\multicolumn{4}{c}{ sampel } \\
\hline Rad & $\mathrm{kVp}$ & $\mathrm{mAs}$ & $\begin{array}{c}\text { Estimasi Dosis } \\
\text { Radiasi Pasien }\end{array}$ \\
\hline 1 & 55 & 8 & 0,194 \\
2 & 58,5 & 8 & 0,225 \\
3 & 60 & 10 & 0,298 \\
4 & 60 & 12,5 & 0,373 \\
5 & 70 & 3,2 & 0,131 \\
6 & 121 & 0,9 & 0,087 \\
7 & 121 & 1 & 0,097 \\
8 & 125 & 1 & 0,101 \\
9 & 125 & 0,9 & 0,091 \\
\hline
\end{tabular}

Dari tabel 4 dapat dilihat bahwa nilai estimasi dosis terendah adalah $0,091 \mathrm{mGy}$ terdapat pada radiograf 9 dan nilai estimasi dosis tertinggi adalah 0,373 mGy terdapat pada radiograf 4 .

Estimasi dosis radiasi didapatkan oleh pasien secara langsung sangat dipengaruhi oleh nilai faktor eksposi terutama pada peningkatan nilai mAs karena nilai mAs merupakan kuantitas dari keluaran radiasi, sehingga berbanding lurus dengan dosis.

\section{Simpulan}

Faktor eksposi akan mempengaruhi nilai Signal To Noise Ratio (SNR). Faktor eksposi meningkat maka menghasilkan lebih banyak sinyal yang mencapai detektor yang membuat noise berkurang.

Penggunaan teknik $\mathrm{kVp}$ tinggi lebih dari 100 $\mathrm{kVp}$, menyebabkan perbedaan densitas antar tulang, jaringan dan udara menjadi relatif homogen sehingga detail dan kontras semakin menurun.

Estimasi dosis radiasi didapatkan oleh pasien secara langsung sangat dipengaruhi oleh nilai faktor eksposi terutama pada peningkatan nilai mAs karena nilai mAs merupakan kuantitas dari keluaran radiasi.

\section{Daftar Pustaka}

Ackom, D., Inkoom, S., Sosu, E., \& Schandorf, C. (2017). Assessment of Image Quality and Radiation Dose to Adult Patients undergoing Computed Radiography Examinations. International Journal of Scientific Research in Science and Technology, 3(8), 89-94. https://doi.org/10.32628/IJSRST173825

Ball, J. L., Price, T., \& Moore, A. D. (1995). Chesneys' Radiographic Imaging (6th ed.). Blackwell Science.

Bequet, A. Y., Rusyadi, L., \& Fatimah, F. (2020). Nilai Contrast to Noise Ratio (CNR) Radiograf Thorax PA antara menggunakan Grid dengan tanpa Menggunakan Grid. Jurnal Imejing Diagnostik (JImeD), 6(2), 6064. https://doi.org/10.31983/jimed.v6i2.5653

Bushong, S. C. (2013). Radiologic Science for Technologist: Physics, Biology, and Protection.

Carlton, R. R., \& Adler, A. M. (2001). Principles of Radiographic Imaging An Art and Science $3 r d$ Edition (Third Edition).

Daryati, S., Indrati, R., \& Illahi, N. W. (2019). Description of Serap Dosagein Examination of Children Thorax Radiograph in Pulmonary Hospital Radiology Installation, Dr. Ario Wirawan Salatiga. Jurnal Imejing Diagnostik (JImeD), $\quad 5(1), \quad 31$. https://doi.org/10.31983/jimed.v5i1.4004

Hastuti, T. P., Kartikasari, Y., Abimanyu, B., \& Sulaksono, N. (2020). Analisis Informasi Citra Anatomi MSCT Thorax dengan Kasus Efusi Pleura Kanker Paru pada Window Mediastinum Post Kontras menggunakan Variasi Nilai Window Width. Jurnal Imejing Diagnostik (JImeD), 6(1), 28-35. https://doi.org/10.31983/jimed.v6i1.5562

Rasad, S. (2018). Radiologi Diagnostik (2nd ed.). FKUI.

Uffmann, M., \& Schaefer-Prokop, C. (2009). Digital Radiography: the balance between 
image quality and required radiation dose.

European Journal of Radiology, 72(2), 202-

208.

https://doi.org/10.1016/j.ejrad.2009.05.060

Utami, A. P., Saputro, S. D., \& Felayani, F. (2014).

Radiologi Dasar I. Inti Medika Pustaka. 